\title{
The Mediation Effects of Business Strategy on the Relations between Industrial Competition and Performance
}

\author{
Estanislau de Sousa Saldanha \\ Senior Lecturer of the Master of Business Administration (MBA) Program \\ Dili Institute of Technology, Timor-Leste \\ Email: estanislausaldanha@yahoo.com
}

\begin{abstract}
This study aims to examine the mediation effects of differentiation strategy and cost leadership strategy on the relationship between industrial competition and the performance of the higher education industry in Timor-Leste. The total of 157 departments of 11 accredited tertiary institutions in Timor-Leste were chosen to fill in the questionnaires, while SMART-PLS 3.0 was used to test the hypothesis. The results of this study show that industrial competition does not significantly influence industrial performance, while both the differentiation and the cost leadership strategies fully mediate the relationship between industrial competition and the performance. This research contributes to the debate on competitive strategic fitness to sustain competitive advantage in regard to pure strategy or combined strategy which is still unsettled among researchers. This research also contributes to developing strategic policies in the higher education industry for improving competitive advantages which lead to superior performance. The higher education industry can also benefit from this research by considering a combined differentiation and cost leadership strategy as a competitive strategy to improve industrial performance.
\end{abstract}

Keywords: Industrial competition, differentiation strategy, cost leadership strategy, combined strategy, industrial performance, industry, higher education.

\section{Introduction}

Industrial organizations seek to develop strategic fitness to maintain competitive advantages and outperform their competitors. Strategic contingency theory states that effective strategies should fit the specific features of the environment in which industrial organizations do business (Baack and Boggs, 2008). Well-established business strategies such as the differentiation strategy, cost leadership strategy, organization resource and capability strategy (resource-based theory) become the distinguishing sources of industrial competitive advantage and performance (Porter, 1980; Barney, 1991; Kim et al., 2016).

Resource-based theory states that industrial organizations have heterogeneous resources and capabilities, therefore, they have different performances. An industrial organization is able to outperform its competitors because it is distinctive, has uniqueness value, is rare, or has inimitable resources and capabilities compared to competing organizations (Silva et al., 2017; Savino and Shafiq, 2018; Mikalef et al., 2019). Conversely, Porter's competitive strategy involves an industrial organization adopting either differentiation strategy or cost leadership strategy to sustain competitive advantage, leading to superior performance. Therefore, Industrial organizations cannot adopt both strategies simultaneously, otherwise industrial organization will confront what is called "stuck-in-the middle", which leads to poor performance (Porter, 1980, 1985; Kaliappen and Hilman, 2017).

Porter's competitive strategy has been widely criticized with the view that use of a pure strategy will be not help an organization retain its competitive position in dealing with the current high industrial competition, new entrance with better resources and capabilities, a high degree of imitation, uncertainty and complexity of the current industrial environment, and rapid technological innovation. Therefore, many researchers offer a combination of strategy or hybrid strategy as an alternative choice for this dynamic industrial environment. This combination strategy or hybrid strategy has attracted many researchers (Hansen et al., 2015; Salavou, 2015; Gabrielsson et al., 2016; Saldanhaet al., 2019; Tavalaei and Santalo, 2019).

Up to now, studies on the combination of differentiation and cost leadership strategy are widely carried out in the manufacturing and banking industry with varied results, while the higher education industry gets less attention. Yet the higher education industry in Timor-Leste experiences a high intensity of competition in line with the massive growth of institutions and study programs, as well as limited resources and capabilities in small market size which places its sustainable performance at risk.

This research aims to fill the above-mentioned research gap by examining the role of combined differentiation strategy and cost leadership strategy on the relations between industrial competition and performance of higher the education industry. Timor-Leste is a new and small country experiencing high growth of higher education institutions and departments in a small market. This has triggered high intensity of industrial competition leading to poor performance. The higher education industry needs to find strategic fitness to fulfill customer demand in getting competency-based performance of higher education industry at reasonably prices. In terms of theory, this research contributes to the unsettled debate on pure strategy versus combined strategy in the context of the higher education industry. Practically, it will enlighten the government and policy 
makers who might consider combined strategies as an alternative approach toward sustainable performance of the higher education industry.

\section{Theoretical Frameworks and Hypothesis 2.1. Industrial competition and performance}

There are two main ways in the literature on strategic management to attempt to explain the competitive advantage of industrial organizations. The resource-based view theory focuses on industrial organization effects, whereas industrial organization emphasises the industry environment as the critical factor for determining competitive advantage and superior performance (Huang and Lee, 2012; González-Rodríguez et al., 2018).

The first view states that industrial competition can be triggered by five competitive forces, namely rivalry, threat of substitutes, threat of new entrants, power of buyers, and power of suppliers (Porter, 1980). Industrial organization performance is negatively related to the strength of market competition because industrial organizations exhaust their resources in dealing with competitive forces (Sun and Lee, 2019) which has implications for the rate of return on invested capital (Hunt and Madhavaram, 2019). Industrial organizations with sustainable performance would be those that are less prone to external shocks (Banker et al., 2014) and creates more economic value than its competitors (de Haan, 2015).

The second view states that Industrial competition is triggered by the internal factors of an industrial organization. Following this theory, industrial organizations have heterogeneous and immobility resources which lead to different competitive positions and performance (Barney, 1991). Industrial organizations which have valuable, rare, imperfectly imitable and non-substitutable resources and capabilities have better competitive advantage than their rivals (Barney, 1991; Savino and Shafiq, 2018; Busby, 2019). An industrial organization's efficiency and effectiveness depend strongly on its resources because it may help to develop strong strategic capabilities (Savino and Shafiq, 2018) by properly matching its resources and strategy to achieve high competitive advantage leading to superior performance (Xie et al., 2018). Therefore, internal strengths in the form of capabilities will determine competitive advantage and performance of an industrial organization (Bobe and Kober, 2015). Most of the resources of an industrial organization are located inside the organization itself, successful strategy must place a premium on acquiring, developing, creating, and re-investing in the requisite resources to produce the market offerings (Hunt and Madhavaram, 2019).

Industrial organizations need to consider both external and internal environments simultaneously when formulating and implementing business strategies, as performance depends on the fit between the capabilities and resources of an organization (González-Rodríguez et al., 2018). Combining the resourcebased theory and industry environment theory, an industrial organization that has better resources and capabilities will gain a better position in dealing with external forces. In this regard, increasing competition positively affects industry performance. Industrial organization with better resources and capabilities will optimally capture outside opportunities, and neutralize outside risks to gain competitive advantage leading to superior performance. In this situation, industrial organizations use their superior resources and capabilities to develop strategic capabilities and innovation to create and offer new values in response to changing customer demands. By contrast, in an industrial organization with limited resources and capabilities, increasing competition adversely affects its performance. A limited resource organization will not be able to take risks to invest its limited resources and lacks capabilities to undertake innovation and create new values in the high intense of industrial competition.

Huang and Lee (2012) found that the five competitive forces had no significant effect on higher education industry performance. This finding was also confirmed by the study of Saldanha et al. (2018) and Saldanha et al. (2019) in TimorLeste. This non-significant correlation might be due to leaders of higher education institutions being well-positioned to address the challenges of domestic and international competition in order to sustain its performance (Huang and Lee, 2012).

In the light of these results, this study is based on the following hypothesis, as the first of four hypotheses to be tested:

H1: Industrial competition has no significant effect on the performance of the higher education industry.

\subsection{Industrial competition, differentiation strategy, and industrial performance}

An industrial organization's strategy and the external environment determines its performance. In many cases, an industrial organizations can adopt a generic strategy in one market and a specialist strategy in another, reflecting market conditions and its own resource constraints (Xie et al., 2018). Differentiation strategy is one dimension of Porter's generic strategy which consists of differentiation strategy, cost leadership strategy and focus (Porter, 1980). When using a differentiation strategy, a company focuses effort on providing a unique product or service, setting their offerings apart from competitors. Product differentiation fulfills a customer need and involves uniquely tailoring the product or service to the customer (Akan et al., 2006). Industrial organizations differentiate themselves in several ways: service quality, and product uniqueness (Miles, 2013).

Differentiation involves an industrial organization's attempts to introduce products or services that are different from competitors, thus enabling the industrial organization to build customer loyalty and command premium prices (Liu and Atuahene-Gima, 2018). Differentiation strategy can help organizations to use attributes of technology, location, 
knowledge, skills and experience to offer superior services, creative advertising, good supplier relationships, market segmentation and branding (Kaliappen and Hilman, 2017) to achieve competitive advantage and superior performance (Porter, 1980; Akan et al., 2006; Sun and Lee, 2019). The differentiation strategy is effectively implemented when the business provides unique or superior value to the customer through product quality, features, or after-sale support and service.

Numerous researchers have found that differentiation strategy positively and significantly affects industrial organization performance (Hansen et al., 2015; Kaya, 2015; González-Rodríguez et al., 2018; Al-Surmi et al., 2019). Therefore, this research proposes the following hypothesis:

H2: Differentiation strategy plays a significant role in mediating the relationship between industrial competition and performance of the higher education industry.

\subsection{Industrial competition, cost leadership, and industrial performance}

A cost leadership strategy seeks to gain competitive advantage by being the lowest cost producer in the industry. This often involves creating efficient scale facilities, rigorous pursuit of cost reductions, and tight controls on overheads, as well as cost minimizations in R\&D, service, sales, marketing and advertising (Porter, 1980; Miles, 2013; Kaliappen and Hilman, 2017). Industrial organizations that pursue an cost leadership strategy should be able to increase their market share based on a low-cost position (Sun and Lee, 2019) in order to sustain superior profitability over time (Banker et al., 2014). Cost leadership strategy offers low-cost products to satisfy price-sensitive customers, specialization in certain products and services as well as efficient use of technology and shortening the distribution channels to reduce costs (Lorenzo et al., 2018). Therefore, this research has proposed the following hypothesis.

H3: Cost leadership strategy plays a significant role in mediating the relationship between industrial competition and performance of the higher education industry.

\subsection{Industrial Competition, combined strategy, and industrial performance}

A combination strategy or hybrid strategy is a strategy which integrates differentiation strategy and cost leadership strategy to achieve strong competitive advantages and superior performance Saldanha et al., 2019). Alternatively, a combination strategy can also integrate Porter's competitive strategy with resource-based strategy or other contingency strategies which fit the industrial environment leading to sustainable performance (Saldanha et al., 2019). Cost leadership provides competitive advantage by providing lowest price, whereas differentiation provides an edge over its competitors by offering different and unique features to its products or services. For example Tesco, Canon, Toyota and IKEA offer combined low-cost and differentiation in a wide range of products or services (Soltanizadeh et al., 2016).

Numerous studies have been carried out on combined strategy integrating differentiation strategy and cost leadership strategy (Claver-Cortés et al., 2012; Hansen et al., 2015; Gabrielsson et al., 2016), and cost leadership strategy and service quality (Saldanha et al., 2019). Their results are as yet inconsistent. For example, Hansen et al. (2015), Yuliansyah, et al. (2016), and Tavalaei and Santalo (2019) found that a combined strategy is not significant enhancer of industrial performance, instead confirming Porter's pure industrial strategy as the better strategy to enhance industrial competitive advantages gaining superior performance. Conversely, numerous researchers have found that combined strategy had positive and significant effect on business performance compared to pure strategy (Claver-Cortés, Pertusa-Ortega and Molina-Azorín, 2012; Salavou, 2013; Gabrielsson, Seppäläb and Gabrielsson, 2016; Saldanha et al., 2019).

\section{H4: A combination of strategies play a full role in mediating the relationship between competition performance industry with higher education industry.}

\section{Research Methods \\ 3.1. Population, Sample and Data Collection}

To test the hypotheses, data were collected via a structured questionnaire. Using information obtained from the TimorLeste National Commission for Academic Assessment and Accreditation (NCAAA), all 157 heads of departments of 11 accredited higher education institutions in Timor-Leste were selected as sample. Therefore, 157 questionnaires were distributed to the Heads of Departments. Of these, 130 questionnaires were filled out, returned and used, which gave a response rate of $83 \%$. This rate is quite high when compared to similar studies undertaken by Huang and Lee (2012) (67.29\%), Garwe (2016) (61.7\%), and Hussein et al. (2016) (66.7 \%). Low response rate may affect the results of the study (Fogliani, 1999; Sivo, Saunders and Jiang, 2004), as it can lead to a high nonresponse bias (Fincham, 2008).

The variables were measured using indicators from previous authors that had been tested its validity and reliability. Industrial competition was measured using Porter's five competitive forces, adopted from Huang and Lee (2012), Saldanha et al. (2018) and Saldanha et al. (2019). Differentiation strategy was adopted from Saldanha et al. (2018), and Cost leadership strategy adopted from Saldanha et al. (2019). Higher education industrial performance was measured using four-dimensions (learning and teaching, research, community service, and finance and marketing), and its indicators were adopted from 
Huang and Lee (2012), Asif and Searcy (2014), and Saldanha et al. (2018).

\subsection{Data Analysis}

Smart-partial least square (Smart-PLS 3.0) was used to analyze data due to its ability to perform multivariate analysis, handle small sample size, and cope with non-normal data (Hopkins, 2015), formative or reflective indicators (Hair et al., 2014). It is also a well-established analytical tool for the study of management and strategy (Valaei, 2017).

Analysis was carried out in two phases. In the first, the outer analysis measurement models are usually carried out to test the validity and reliability of indicators of constructs. Analysis of reliability using parameters such as Cronbach alpha (CA) and composite reliability (CR). An indicator is considered reliable if the value of CA is greater than 0.7 , and $C R$ is also greater than 0.7 (Hair et al., 2017). Two typical validity analyses were used in this research, namely convergent validity with outer loading of each indicator with a minimum value of 0.7 , and average variance extracted (AVE) is greater than 0.5 (Hair et al., 2014; and Hopkins, 2015). The discriminant validity can use FornellLarscker criterion, cross loadings and heterotrait-monotrait ratio (HTMT0.85) (Hair et al., 2014; Henseler, Ringle and Sarstedt, 2015; Hair et al., 2017).

In the second phase, the inner measurement models were used to examine the relationship between variables. Each hypothesis is tested with the value of $\mathrm{T}$ and $\mathrm{P}$ values in path coefficient analysis with a minimum threshold value $\mathrm{T}$ was 1.96 and the limit value of $\mathrm{P}$ is less than 0.05 (Hair et al., 2014).

\section{Results}

\subsection{Reliability and Validity}

Based on the construct reliability test using Smart-PLS 3.0, the values of composite reliability $(\mathrm{CR})$ and Cronbach alpha (CA) exceeded the acceptable level. Table I shows the values of
CA and CR of all items greater than 0.7 , with only the value of IC item being below 0.7 . Nonetheless, the $\mathrm{CR}$ value of the IC item is above the threshold level (Hair et al., 2014; Roemer, 2016; Hair et al., 2017) which does not affect the reliability, and content validity (Hair et al., 2014). Therefore, the reliability of all constructs is accepted.

Table I. Results of the reliability test

\begin{tabular}{c|ccc}
\hline ITEM & CA & CR & AVE \\
\hline IC & 0.595 & 0.777 & 0.539 \\
DS & 0.764 & 0.862 & 0.677 \\
IC1 & 0.627 & 0.839 & 0.724 \\
IC2 & 0.731 & 0.849 & 0.655 \\
IC3 & 0.785 & 0.862 & 0.610 \\
IC4 & 0.681 & 0.825 & 0.613 \\
IC5 & 0.711 & 0.837 & 0.633 \\
IP1 & 0.823 & 0.883 & 0.655 \\
IP2 & 0.854 & 0.901 & 0.696 \\
IP3 & 0.826 & 0.920 & 0.851 \\
IP4 & 0.926 & 0.948 & 0.819 \\
\hline
\end{tabular}

The validity of this model was tested using convergent validity (outer loading and average variance extracted/AVE) and discriminant validity. Figure 1 and Table 1 show that convergent validity based on the outer loading of all indicators meet the minimum threshold of 0.7 , with the exception of two indicators with an outer loading values below 0.7 but above 0.6 . According to Hair et al. (2014), the minimum value of outer loading for exploratory research is 0.6 . The convergent validity of AVE values of all constructs greater than 0.5 (Table 1), which mean all constructs in this model have good convergent validity.

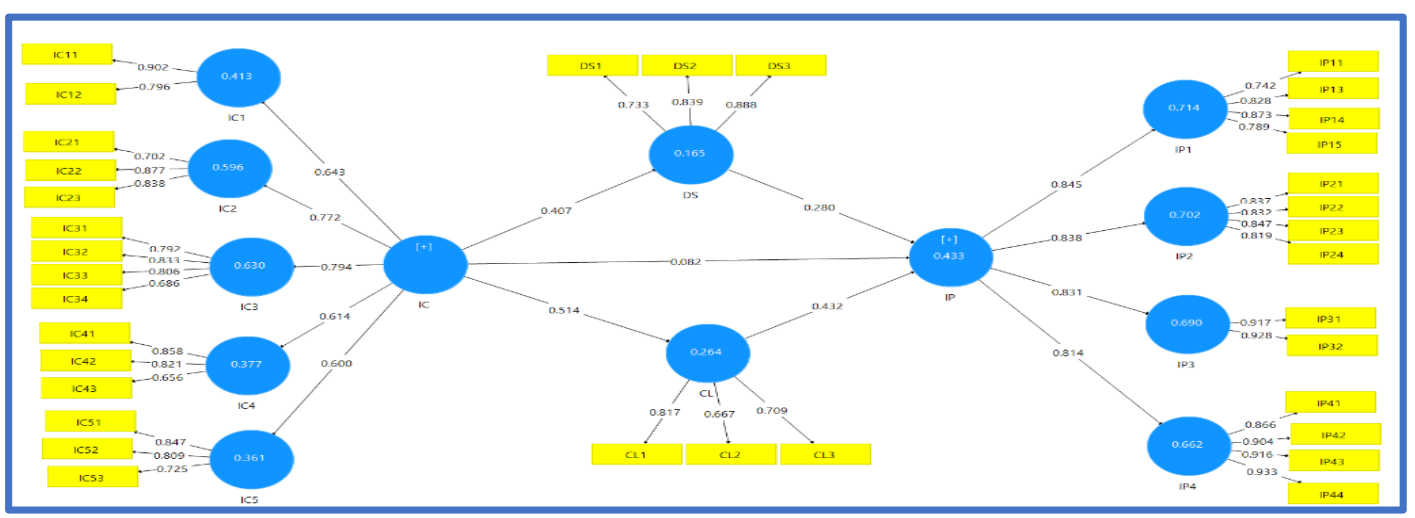

Figure 1. Results of the SMART-PLS Algorithm for outer measurement test.

The discriminant validity using Fornell-Larcker Criterion, and HTMT. The results show that the Fornell-Larcker Criterion based on the off-diagonal values are the correlations between the latent constructs and the diagonals are square values of AVE, which prove that AVEs on its own construct are higher compared to all of its loadings with the other constructs (Table 
Vol.1, No.1, Issue.1, pp.1-11, 2019

Available online at: https://tljbm.org/jurnal/index.php/tljbm

II). This meets the minimum threshold as recommended value (Hair et al, 2014; Hopkins, 2015; Hair et al. (2017). In addition, the value HTMT0.85 (Table III) for all variables is below the maximum recommended value of 0.85 (Henseler, Ringle and Sarstedt, 2015; Hair et al., 2017). Accordingly, all constructs are valid based on the discriminant validity test.

Table II. Fornell-Larcker Criterion value

\begin{tabular}{|c|c|c|c|c|c|c|c|c|c|c|c|}
\hline & CL & DS & IC1 & IC2 & IC3 & IC4 & IC5 & IP1 & IP2 & IP3 & IP4 \\
\hline CL & 0.734 & & & & & & & & & & \\
\hline DS & 0.437 & 0.823 & & & & & & & & & \\
\hline IC1 & 0.278 & 0.225 & 0.851 & & & & & & & & \\
\hline IC2 & 0.317 & 0.222 & 0.479 & 0.809 & & & & & & & \\
\hline IC3 & 0.377 & 0.364 & 0.408 & 0.515 & 0.781 & & & & & & \\
\hline IC4 & 0.378 & 0.227 & 0.180 & 0.275 & 0.416 & 0.783 & & & & & \\
\hline IC5 & 0.244 & 0.174 & 0.281 & 0.438 & 0.300 & 0.263 & 0.796 & & & & \\
\hline IP1 & 0.598 & 0.507 & 0.166 & 0.334 & 0.315 & 0.262 & 0.193 & 0.809 & & & \\
\hline IP2 & 0.461 & 0.348 & 0.050 & 0.147 & 0.206 & 0.270 & 0.064 & 0.612 & 0.834 & & \\
\hline IP3 & 0.477 & 0.386 & 0.155 & 0.182 & 0.255 & 0.097 & 0.098 & 0.588 & 0.594 & 0.923 & \\
\hline IP4 & 0.407 & 0.365 & 0.221 & 0.336 & 0.276 & 0.290 & 0.210 & 0.520 & 0.634 & 0.613 & 0.905 \\
\hline
\end{tabular}

Table III. Value of Heterotrait-Monotrait (HTMT) discriminant validity.

\begin{tabular}{|c|c|c|c|c|c|c|c|c|c|c|c|}
\hline & CL & DS & IC1 & IC2 & IC3 & IC4 & IC5 & IP1 & IP2 & IP3 & IP4 \\
\hline DS & 0.589 & & & & & & & & & & \\
\hline IC1 & 0.394 & 0.293 & & & & & & & & & \\
\hline $\mathrm{IC} 2$ & 0.425 & 0.292 & 0.716 & & & & & & & & \\
\hline $\mathrm{IC3}$ & 0.517 & 0.449 & 0.570 & 0.679 & & & & & & & \\
\hline IC4 & 0.604 & 0.306 & 0.290 & 0.378 & 0.565 & & & & & & \\
\hline IC5 & 0.387 & 0.274 & 0.395 & 0.608 & 0,407 & 0.378 & & & & & \\
\hline IP1 & 0.782 & 0.625 & 0.248 & 0.425 & 0.387 & 0.339 & 0.254 & & & & \\
\hline IP2 & 0.592 & 0.423 & 0.227 & 0.185 & 0.248 & 0.344 & 0.174 & 0.731 & & & \\
\hline IP3 & 0.645 & 0.449 & 0.200 & 0.227 & 0.307 & 0.133 & 0.157 & 0.711 & 0.706 & & \\
\hline IP4 & 0.496 & 0.424 & 0.272 & 0.406 & 0.325 & 0.352 & 0.261 & 0.594 & 0.709 & 0.700 & \\
\hline
\end{tabular}

\subsection{Hypothesis Test Results}

The hypothesis testing using bootstrapping Smart-PLS 3.0 to test T and P values. The result of direct effect of the relations between the industrial competition (IC) and industrial performance (IP) show that the T value is 0.831 and the P value is 0.406 (Figure 2 and Table IV) which means the $\mathrm{T}$ value is lower than the maximum limit of 1.96 and the $\mathrm{P}$ value is greater than the minimum acceptable value of 0.05 (Hair et al., 2014). Therefore, H1 is acceptable. 


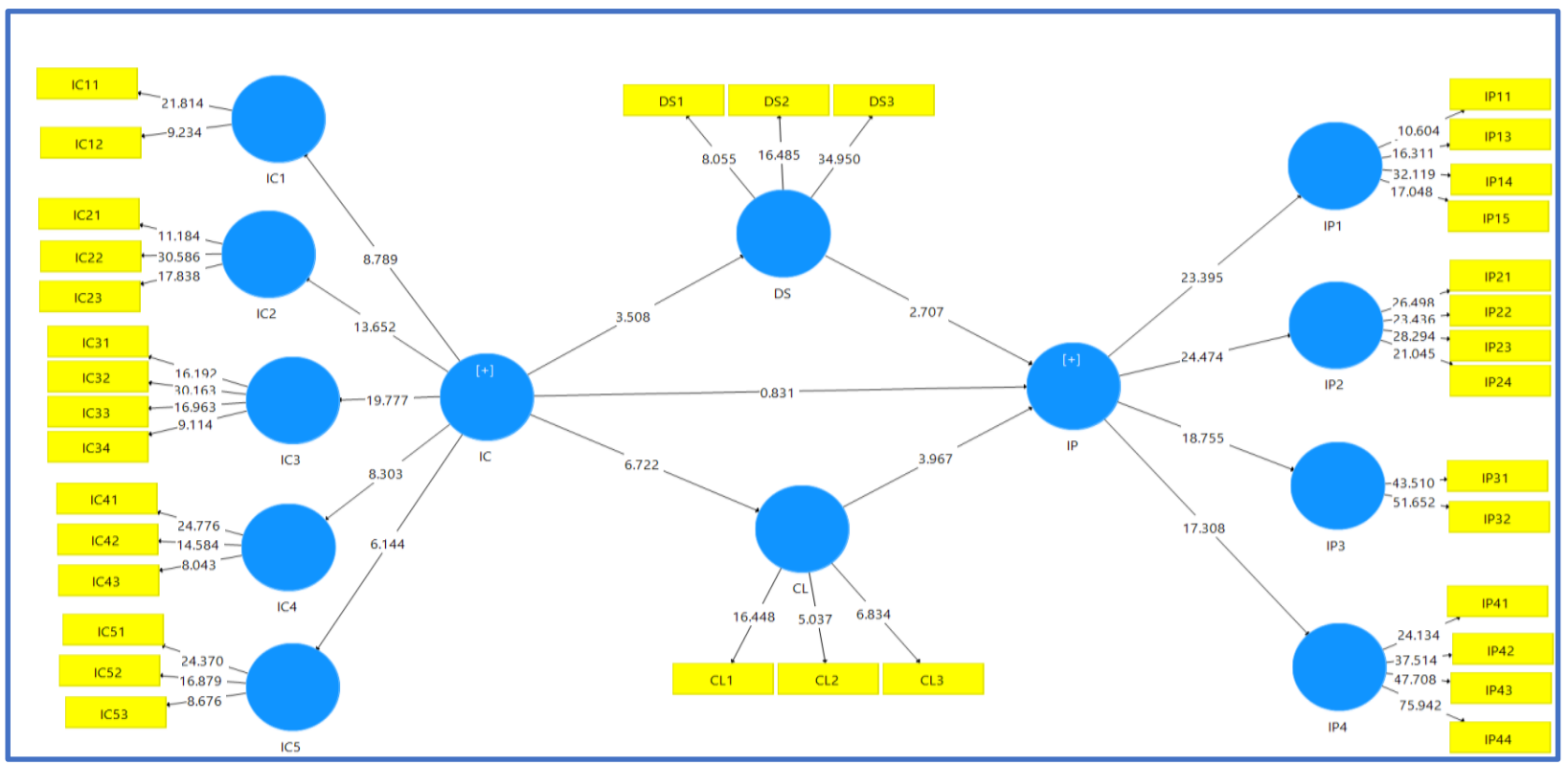

Figure 2. Results of hypothesis test using bootstrapping SMART-PLS 3.0.

Table IV shows the results of the bootstrapping SMART-PLS of the direct effects of the relationship between variables. The results show that the relationships between all variables in the model are positive and significant ( $\mathrm{T}$ values greater than 1.96, and $\mathrm{P}$ value less than 0.05), except the relationship between industrial competition (IC) and industrial performance (IP) which is not significant (T value lower than 1.96 and $\mathrm{P}$ value greater than 0.05$)$.

Table IV. Results bootstrapping direct effects ( $T$ and $P$ values).

\begin{tabular}{|c|c|c|c|c|c|c|}
\hline & $\begin{array}{l}\text { Original } \\
\text { Sample } \\
\text { (O) }\end{array}$ & $\begin{array}{l}\text { Sample } \\
\text { Mean } \\
\text { (M) }\end{array}$ & $\begin{array}{l}\text { Standard } \\
\text { Deviation } \\
\text { (STDEV) }\end{array}$ & $\begin{array}{l}\text { T Statistics ( } \\
\text { O / STDEV } \\
\text { () }\end{array}$ & $\begin{array}{c}\mathbf{P} \\
\text { Values }\end{array}$ & Note \\
\hline $\mathrm{CL}->\mathrm{IP}$ & 0.432 & 0.424 & 0.109 & 3.967 & 0.000 & Significant \\
\hline DS -> IP & 0.280 & 0.284 & 0.104 & 2.707 & 0.007 & Significant \\
\hline $\mathrm{IC}>\mathrm{CL}$ & 0.514 & 0.536 & 0.076 & 6.722 & 0.000 & Significant \\
\hline IC $\rightarrow$ DS & 0.407 & 0.423 & 0.116 & 3.508 & 0.000 & Significant \\
\hline IC -> IP & 0.082 & 0.108 & 0.099 & 0.831 & 0.406 & Not significant \\
\hline
\end{tabular}

Table IV shows the results of the specific indirect effect test from bootstrapping Smart-PLS 3.0 on the role of differentiation strategy (DS) in mediating the relationship between industrial competition (IC) and industrial performance (IP). The T value exceeded the minimum threshold value $(\mathrm{T}=1.96)$ and $\mathrm{P}$ value below the maximum level ( $\mathrm{P}=0.05$ ) (Hair et al., 2014), which mean differentiation strategy fully mediated the relationship between industrial competition and performance. Therefore, $\mathrm{H} 2$ is acceptable.

In testing the mediating effect cost leadership strategy (CL) on the relationship between industrial competition (IC) and industrial performance (IP), the specific indirect effects of bootstrapping Smart-PLS 3.0 shows that the T value is above the minimum limit $(\mathrm{T}=1.96)$, while the $\mathrm{P}$ value is below the maximum limit $(\mathrm{P}=0.05)$ (Table IV) (Hair et al., 2014). This suggests that the cost leadership strategy (CL) fully mediates the relationship between industrial competition (IC) and industrial performance (IP). Therefore, H3 is acceptable.

In the mediation effects of combined differentiation strategy (DS) and cost leadership strategy (CL) on the relationship between industrial competition (IC) and industrial performance (IP), the results of bootstrapping Smart-PLS 3.0 show that the total indirect effects based on the T value equals to 4.577 and the $\mathrm{P}$ value equals 0.000 . Thus the $\mathrm{T}$ value exceeds the minimum threshold value $(\mathrm{T}=1.96)$ and the $\mathrm{P}$ value is below the maximum limit value $(\mathrm{P}=0.05)$ (Hair et al., 2014). The values of $\mathrm{T}$ and $\mathrm{P}$ of the total effects are greater than the specific effects of DS and CL on the relationship between industrial competition (IC) and industrial performance (IP) (Table IV). This shows that the DS and CL cumulatively played an important role in 
mediating the relationship between IC and IP compared to the specific role of mediation between the two variables.

Table IV. Specific bootstrapping results of indirect and total indirect effects (test value $\mathbf{T}$ and $\mathbf{P}$ ).

\begin{tabular}{|c|c|c|c|c|c|c|}
\hline & $\begin{array}{l}\text { Original } \\
\text { Sample } \\
(0)\end{array}$ & $\begin{array}{l}\text { Sample } \\
\text { Mean (M) }\end{array}$ & $\begin{array}{l}\text { Standard } \\
\text { Deviation } \\
\text { (STDEV) }\end{array}$ & $\begin{array}{l}\text { T Statistics (| } \\
\text { O / STDEV |) }\end{array}$ & $\begin{array}{c}\mathbf{P} \\
\text { Values }\end{array}$ & Note \\
\hline \multicolumn{7}{|l|}{ Specific indirect effects } \\
\hline IC $\rightarrow$ DS $\rightarrow$ IP $\rightarrow$ IP1 & 0.096 & 0.101 & 0.049 & 1.984 & 0.048 & Significant \\
\hline IC $>$ DS $>$ IP $>$ IP2 & 0.096 & 0.100 & 0.047 & 2.027 & 0.043 & Significant \\
\hline IC $->$ DS $>$ IP $>$ IP3 & 0.095 & 0.099 & 0.047 & 2.022 & 0.044 & Significant \\
\hline IC $\rightarrow>$ DS $>$ IP $>$ IP4 & 0.093 & 0.098 & 0.047 & 1.976 & 0.049 & Significant \\
\hline $\mathrm{IC}>\mathrm{CL} \rightarrow \mathrm{IP} \rightarrow \mathrm{IP1}$ & 0.187 & 0.191 & 0.059 & 3.200 & 0.001 & Significant \\
\hline $\mathrm{IC} \rightarrow \mathrm{CL}>\mathrm{IP} \rightarrow \mathrm{IP2}$ & 0.186 & 0.190 & 0.056 & 3.308 & 0.001 & Significant \\
\hline IC $\rightarrow$ CL $>$ IP $>$ IP3 & 0.184 & 0.188 & 0.057 & 3.229 & 0.001 & Significant \\
\hline $\mathrm{IC} \rightarrow \mathrm{CL} \rightarrow \mathrm{IP} \rightarrow \mathrm{IP} 4$ & 0.180 & 0.184 & 0.057 & 3.178 & 0.002 & Significant \\
\hline \multicolumn{7}{|l|}{ Total Indirect effects } \\
\hline IC $>$ IP & 0.336 & 0.347 & 0.073 & 4.577 & 0.000 & Significant \\
\hline
\end{tabular}

\section{Discussion}

The results of this study demonstrate that industrial competition did not significantly affect the performance of the higher education industry in Timor-Leste. Therefore, external factors such as competitive rivalry, power of suppliers, power of buyers, threat of substitutes, and threat of new entrants do not significantly affect the performance of learning and teaching, research, community service, finance and marketing of the higher education industry. This finding is consistent with the study of Assaf and Cvelbar (2011), Huang and Lee (2012), Saldanha et al. (2018), and Saldanha et al. (2019), while asymmetrical link with the view of the Porter's competitive forces (Porter, 1980), Metts (2007) and Jin et al. (2014) as well as the study of Lee and Yang (2011) and Obembe and Soetan (2015) that industrial competition does significantly affect industrial performance. The inconsistency in research results might partly be due to differences of industrial organizations in resources and capabilities, size, industrial environment, and type (Saldanha et al., 2019). Different resources and capabilities become determinant factors leading to different competitive advantages and performances (Barney, 1991). Industrial organizations with good, unique, valuable and inimitable resources and capabilities will lead to superior competitive advantages and performance better than its competitors (Barney, 1991; Bobe and Kober, 2015).

The results from specific indirect effects show that the cost leadership strategy has a more significant role in mediating the relationship between industrial competition and performance compared with differentiation strategy (Table IV). This is because cost control and efficiency, and unit cost control help to provide products and services at lower costs to enhance market share compared to its competitors. This study confirms the studies of Acquaah (2013) and of Saldanha et al. (2018).

Both differentiation strategy and cost leadership strategy will effectively work in perfectly labour market competitive country. In a competitive labour market country, industrial organizations are encouraged to improve efficiency by developing their organizational capabilities to produce high quality products and services based on customer demand. Conversely, in imperfect competitive labour market countries, people can get jobs easily if they have connectivity, even if they have low skills. This will gradually lead to declining competitive advantage and performance, as industrial organizations are reluctant to invest in improving their quality and performance. By contrast, in countries with a perfectly competitive labor market, the labor market requires highly competent graduates. This encourages the higher education industry to make investments in improving the competence and the added value of the graduates which lead to enhance their competitiveness in the labor market.

The results of the total indirect effects of two variables are greater than the role of indirect effects of each variable on the relationship between industrial competition and performance. This suggests that a combination of strategies can better improve the performance of higher education institutions in the competitive industry environment compared to pure strategy.

In developing countries such as Timor-Leste, customers want to get both quality products and services at a reasonable price. Industrial organizations with superior resources and capabilities can develop products and service innovation with high quality and values at the lowest prices in order to meet 
customer demands. In this regard, Lorenzo et al. (2018) state that industrial organizations can use optimal technology in achieving cost reduction, enhancing quality and value creation, leading to high competitive advantage. The use of digital technology such as social media networking can lead to increased positive learning outcomes which enriches the learning activities of students and facilitates group discussions (Al-Rahmi et al., 2018). Higher education industry benefits from using e-education, distance learning, e-assessment, elibrary, and e-administration to get qualified lecturers at reduced cost. Empirically, numerous studies prove that e-education based on information technology can improve the quality of teaching and learning which ultimately contributes to increasing competitive advantages and performance (Bhatt et al., 2010; AlSurmi, Cao and Duan, 2019; Chen, Yang and Yang, 2019; Fleaca, Stanciu and Zanin, 2019; Mikalef et al., 2019).

This study enriches the previous studies of Salavou (2013, 2015), Gabrielsson et al. (2016), Saldanha et al. (2018, 2019), while asymmetrical findings of Hansen et al. (2015) and Yuliansyah et al. (2016) on hybrid or combination strategy. The current finding is not in line with Porter's view that external industry environment adversely affects industry performance, and therefore, to sustain its competitive advantage leading to superior performance, industrial organization must adopt pure strategy, rather than combination strategy.

\section{Conclusions and Implications}

This study shows that industrial competition has no significant effect on the performance of the higher education industry. That is, industrial competition does not necessarily increase or decrease industrial performance. However, at the stage of which higher education industry face human resource shortages, industrial environment complexity, uncertainty, and no significant barriers to new entrances, the higher education industry must improve its performance by tight control on efficiencies, costs, and unit prices as well as improving service quality, and enhancing skill-based outcomes and study programs.

The findings of this study indicate that a combination of strategies of differentiation and cost leadership can improve industrial performance. This is because an industry organization is not able to deal with only one strategy (pure strategy) because it is easily imitated by industry competitors that have implications on industrial organization may lose competitiveness.

In the high intensity of industrial competition, industrial organizations have to provide innovative, unique and high value products and services to customers at more affordable prices. A lower price may lead to an industrial organization enhancing its market share, earning sufficient income to maintain sustainable operations, ensuring quality products and services. In such a context, government can play its regulatory role to encourage industrial organizations to offer differentiated products and services in order to avoid hypercompetition in a limited market segment that threaten the quality, performance and operational sustainability of the higher education industry.

\section{Limitations and Future Research}

This study was conducted to determine the effects of industrial competition on industrial performance as well as to test the mediating role of industrial strategy on the relationship between industrial competition and industrial performance. The test only focused on the external environment as the major factor in determining the relations between industrial competition and performance. However, internal factors can also be major factors triggering industrial competition. Therefore, future research should also consider internal factors as triggers for industrial competition. The current study only looked at the institutional perspectives (or service providers), but did not look at the side of the service users such as students, government, and industry as the target respondents. Furthermore, the combination strategy was only done in terms of Porter's generic strategy, which ignores other combination strategies such as resource-based view, market orientation strategy and entrepreneurial strategies. Therefore, future research can also analyse such strategies in order to examine industrial performance.

\section{References:}

Acquaah, M. (2013) 'Management control systems, business strategy and performance: A comparative analysis of family and non-family businesses in a transition economy in sub-Saharan Africa', Journal of Family Business Strategy. Elsevier Ltd, 4 (2), pp.131-146.

Akan, O. et al. (2006) 'Critical tactics for implementing Porter's generic strategies', Journal of Business Strategy, 27 (1), pp.4353.

Al-Rahmi, W. M. Alias, N., Othman, M.S., Marin, V.I. and Tur, G. (2018) 'A model of factors affecting learning performance through the use of social media in Malaysian higher education', Computers and Education, 121 (April 2017), pp.59-72.

Al-Surmi, A., Cao, G. and Duan, Y. (2019) 'The impact of aligning business, IT, and marketing strategies on industrial organization performance', Industrial Marketing Management, $\operatorname{xxx}(\mathrm{xxx}) \mathrm{xxx}-\mathrm{xxx}$.

Asif, M. and Searcy, C. (2014) 'A composite index for measuring performance in higher education institutions', The International Journal of Quality \& Reliability Management, 31 (9), p.983.

Assaf, A. and Cvelbar, K. L. (2011) 'Privatization, market competition, international attractiveness, management tenure and hotel performance: Evidence from Slovenia', International 
Journal of Hospitality Management, 30 (2), pp.391-397.

Baack, D. W. and Boggs, D. J. (2008) 'The difficulties in using a cost leadership strategy in emerging markets', International Journal of Emerging Markets, 3 (2), pp.125-139.

Banker, R. D., Mashruwala, R. and Tripathy, A. (2014) 'Does a differentiation strategy lead to more sustainable financial performance than a cost leadership strategy?', Management Decision, 52 (5), p.872.

Barney, J. (1991) 'Industrial organization Resources and Sustained Competitive Advantage', Journal of Management, pp.99-120.

Bayar, T., Millon, M., Erhemjamts, O., Leverty, T. and Tehranian, H. (2018) 'An examination of the relation between strategic interaction among industry industrial organizations and industrial organization performance R', Journal of Banking and Finance. Elsevier B. V., 87, pp.248-263.

Bhatt, G., Emdad, A., Roberts, N. and Grover, V. (2010) 'Building and leveraging information in dynamic environments: The role of IT infrastructure flexibility as enabler of organizational responsiveness and competitive advantage', Information and Management. Elsevier B. V., 47 (7-8), pp.341349.

Bobe, B. J. and Kober, R. (2015) 'Measuring organizational capabilities in the higher education sector', Education + Training, 57 (3), pp.322-342.

Busby, J. S. (2019) 'The co-evolution of competition and parasitism in the resource-based view: A risk model of product counterfeiting', European Journal of Operational Research, 276 (1), pp.300-313.

Chen, J., Yang, B. and Yang, L. (2019) 'To BE or not to BE, that is the question', Nature Biotechnology, 37 (5), pp.520-522.

Claver-Cortés, E., Pertusa-Ortega, E. M. and Molina-Azorín, J. F. (2012) 'Characteristics of organizational structure relating to hybrid competitive strategy: Implications for performance', Journal of Business Research. Elsevier Inc., 65 (7), pp.9931002.

Fincham, J. E. (2008) 'Response rates and responsiveness for surveys, standards, and the Journal. ', American journal of pharmaceutical education, 72 (2), p.43.

Fleaca, E., Stanciu, R. D. and Zanin, A. (2019) 'Digital-age Learning and Business Engineering Education - a Pilot Digitalage Learning and Business Engineering Study on Students ' Eskills Education - a Pilot Study on Students' Costing models for', Procedia Manufacturing, 32, pp.1051-1057.

Fogliani, M. (1999) 'Low response rates and their effects on survey results', Methodology Advisory Committee paper,
(November), p.13.

Gabrielsson, M., Seppäläb, T. and Gabrielsson, P. (2016) 'Realizing a hybrid competitive strategy and achieving superior financial performance while internationalizing in the hightechnology market', Industrial Marketing Management. Elsevier Inc., 54, pp.141-153. doi: 1.

Garwe, E. C. (2016) 'Increase in the demand for private higher education: unmasking the "paradox", International Journal of Educational Management, 30 (2).

González-Rodríguez, M.R., Jiménez-Caballero, J.L., MartínSamper, R. C., Köseoglu, M. A. and Okumus, F. (2018) 'Revisiting the link between business strategy and performance: Evidence from hotels', International Journal of Hospitality Management. Elsevier, 72 (November 2017), pp.21-31.

de Haan, H. H. (2015) 'Competitive advantage, what it really mean in the context of public higher education institutions?', Internaltional Journal of Education Management, 29 (1), pp.44-61.

Hair, J., Hollingsworth, C.L., Randolph, A.B., and Chong, A.Y.L. (2017) 'An updated and expanded assessment of PLSSEM in information systems research', Industrial Management \& Data Systems, 117 (3), pp.442-458.

Hair, J.F., Sarstedt, M., Hopkins, L., and Kuppelwieser, V.G. (2014) 'Partial least squares structural equation modeling (PLSSEM)', European Business Review, 26 (2), pp.106-121.

Hair, J.F., Hult, G.T.M, Ringle, C.M., Sarstedt, M. (2014) Partial Least Squares Structural Equation Modeling (Pls-Sem). London: SAGE Publication LTD.

Hansen, E., Nybakk, E. and Panwar, R. (2015) 'Pure versus hybrid competitive strategies in the forest sector: Performance implications', Forest Policy and Economics. Elsevier B. V., 54 (1), pp.51-57.

Henseler, J., Ringle, C. M. and Sarstedt, M. (2015) 'A new criterion for assessing discriminant validity in variance-based structural equation modeling', Journal of the Academy of Marketing Science, 43 (1), pp.115-135.

Hopkins, L. (2015) 'Partial least squares structural equation modeling ( PLS-SEM ) An emerging tool in business research', European Business Review, 26 (2), pp.106-121.

Huang, H. -I. and Lee, C. -F. (2012) 'Strategic management for competitive advantage: a case study of higher technical and vocational education in Taiwan', Journal of Higher Education Policy and Management, 34 (6), pp.611-628.

Hunt, S. D. and Madhavaram, S. (2019) 'Adaptive marketing capabilities, dynamic capabilities, and renewal competences: 
Vol.1, No.1, Issue.1, pp.1-11, 2019

Available online at: https://tljbm.org/jurnal/index.php/tljbm

The "outside vs. inside" and "static vs. dynamic" controversies in strategy', Industrial Marketing Management, (July).

Hussein, N. Omar, S., Noordin, F. and Ishak, N.A. (2016) 'Learning Organization Culture, Organizational Performance and Organizational Innovativeness in a Public Institution of Higher Education in Malaysia: A Preliminary Study', Procedia Economics and Finance. Elsevier B. V., 37 (16), pp.512-519. Omar, S., Noordin, F. and Ishak, N.A.

Jin, D. Liu, J., Liu, L., and Yin, D. (2014) 'Competition and profit hiding: evidence from banks in China', Managerial Finance, 40, pp.1040-1051.

Kaliappen, N. and Hilman, H. (2017) 'Competitive strategies, market orientation types and innovation strategies: finding the strategic fit', World Journal of Entrepreneurship , Management and Sustainable Development, 13 (3), pp.257-261.

Kaya, N. (2015) 'Corporate Entrepreneurship, Generic Competitive Strategies, and Industrial organization Performance in Small and Medium-sized Enterprises', Procedia - Social and Behavioral Sciences. Elsevier B. V., 207, pp.662668.

Kim, N., Shin, S. and Min, S. (2016) 'Strategic marketing capability: Mobilizing technological resources for new product advantage', Journal of Business Research. Elsevier Inc., 69 (12), pp.5644-5652.

Lee, C. -L. and Yang, H. -J. (2011) 'Organization structure, competition and performance measurement systems and their joint effects on performance', Management Accounting Research. Elsevier Ltd, 22 (2), pp.84-104.

Liu, W. and Atuahene-Gima, K. (2018) 'Enhancing product innovation performance in a dysfunctional competitive environment: The roles of competitive strategies and marketbased assets', Industrial Marketing Management, 73 (February), pp.7-20. doi: 10.1016/j. indmarman.2018.01.006.

Lorenzo, J. R. F., Rubio, M. T. M. and Garcés, S. A. (2018) 'The competitive advantage in business, capabilities and strategy. What general performance factors are found in the Spanish wine industry?', Wine Economics and Policy, 7 (2), pp.94-108.

Metts, G. A. (2007) 'Measuring the effectiveness of managerial action in SMEs', Management Research News, 30 (12), pp.892914.

Mikalef, P., Krogstie, J., Pappas, I. O., Pavlou, P. (2019) 'Exploring the relationship between big data analytics capability and competitive performance: The mediating roles of dynamic and operational capabilities', Information and Management, (February 2018).

Miles, P. C. (2013) 'Competitive strategy: the link between service characteristics and customer satisfaction', International
Journal of Quality and Service Sciences, 5 (4), pp.395-414.

Obembe, O. B. and Soetan, R. O. (2015) 'Competition, corporate governance and corporate performance', African Journal of Economic and Management Studies, 6 (3), pp.251271.

Porter, M. E. (1980) Competitive strategy: Techniques for analyzing industries and companies, New York. New York: The Free Press.

Porter, M. E. (1985) Competitive Advantage - Creating and Sustaining Superior Performance, New York: FreePress. New York: The Free Press.

Roemer, E. (2016) 'A tutorial on the use of PLS path modeling in longitudinal studies', Industrial Management \& Data Systems, 116 (9), pp.1901-1921.

Salavou, H. E. (2013) 'Hybrid strategies in Greece: a pleasant surprise', European Business Review, 25 (3), pp.301-314.

Salavou, H. E. (2015) 'Competitive strategies and their shift to the future', European Business Review, 27 (1), pp.80-99.

Saldanha, E. de S., Rahyuda, I. K., Yasa, N. N. K., and Sukaatmadja, I.P.G. (2018) 'The Role of Business Strategy in Mediating the Relationship Between Industrial Competition and Performances: A Study in the Higher Education Industry in Timor-Leste', European Jorunal of Business and Management, 10 (8), pp.152-172.

Saldanha, E. de S., Rahyuda, I. K., Yasa, N. N. K., and Sukaatmadja, I.P.G. (2019) 'Industrial Competition, Hybrid Strategy and Industrial Performance: Study in Higher Education Industry in Timor-Leste', Journal of Engineering and Applied Sciences, 14 (8), pp.2456-2464.

Saldanha, E. de S., Rahyuda, I. K., Yasa, N. N. K., and Sukaatmadja, I.P.G. (2019). Persaingan Industri, Strategi Bisnis, dan Kinerja Industri: Studi Pada Industri Jasa Pendidikan Tinggi', Denpasar: Udayana University Press.

Savino, M. M. and Shafiq, M. (2018) 'An extensive study to assess the sustainability drivers of production performances using a resource-based view and contingency analysis', Journal of Cleaner Production, 204, pp.744-752.

Silva, R., Gerwe, O. and Becerra, M. (2017) 'Corporate brand and hotel performance: A resource-based perspective', Journal of Business Research, 79 (May), pp.23-30.

Sivo, S. A., Saunders, C. and Jiang, J. J. (2004) 'How Low Should You Go? Low Response Rates and the Validity of Inference in IS Questionnaire Research 1', Journal of The Association for Information Systems, 7 (6), pp.351-414. 
Soltanizadeh, S., Rasid, S.Z.A., Golshan, N.M., Ismail, W.K.W. (2016) 'Business strategy, enterprise risk management and organizational performance', Management Research Review, 39 (1016-1033).

Sun, K. A. and Lee, S. (2019) 'Competitive advantages of franchising industrial organizations and the moderating role of organizational characteristics: Evidence from the restaurant industry', International Journal of Hospitality Management, 77 (October 2017), pp.281-289.

Tavalaei, M. M. and Santalo, J. (2019) 'Pure versus hybrid competitive strategies in the airport industry', Transportation Research Part A: Policy and Practice, 124 (April), pp.444-455.
Valaei, N. (2017) 'Organizational structure, sense making activities, and SMEs' competitiveness: An application of conindustrial organizationatory tetrad analysis-partial least squares (CTA-PLS)', VINE Journal of Information and Knowledge Management Systems, 47 (1), p.

Xie, H. Y., Xie, Q. (Jane) and Zhao, H. (2018) 'Foreign industrial organizations' strategic positioning and performance in a host market A resource partitioning perspective', Multinational Business Review, 26 (2), pp.173-192.

Yuliansyah, Y., Rammal, H. G. and Rose, E. (2016) 'Business strategy and performance in Indonesia's service sector', Journal of Asia Business Studies, 10 (2), pp.164-182. 